\title{
Association of Protein Tyrosine Phosphatase Non-receptor, Type 22 (PTPN22) C1858T Polymorphism with Type 1 Diabetes in North India: A Replication Study
}

Rajni Rani*, Neetu Israni, Avinash Kumar, Smreti Vasudevan and Jaya Singh

Molecular Immunogenetics Group, National Institute of Immunology, India

\begin{abstract}
Objective: Type 1 diabetes (T1D) is a multifactorial autoimmune disorder where several genes have been associated with the disease. While the major histocompatibility complex has been shown to be the major locus, contributions of other loci in different combinations seem to have synergistic effects. PTPN22 (Protein tyrosine phosphatase non-receptor, type 22) gene encoding lymphoid tyrosine phosphatase (LYP) is a negative regulator of $T$ cell signaling. A gain of function mutant at nucleotide position $1858 \mathrm{C}>T$ has been associated with diabetes, however, it is reported to be absent in Asians. We have studied PTPN22 C1858T polymorphism in T1D patients from North India since there are no reports from this region.
\end{abstract}

Methods: PTPN22 C1858T polymorphism was studied in 250 T1D patients and 480 healthy controls using polymerase chain reaction followed by restriction digestion (PCR-RFLP). Alleles of HLA-DRB1 locus were studied using PCR followed by hybridization with sequence specific oligonucleotide probes using a bead based assay on Luminex platform.

Results: In spite of reports of absence of $1858 T$ allele in Asians, we observed this allele to be present in North Indians, albeit with low frequency $(1.98 \%)$. However, T1D patients from the same ethnic background showed significantly higher frequency of the allele and heterozygous genotype 1858CT as compared to controls. Patients with both $1858 \mathrm{CT}$ and $1858 \mathrm{CC}$ genotypes had predisposing MHC alleles.

Conclusion: The association of PTPN22 1858CT genotype with Type 1 diabetes was independent of the predisposing Human leukocyte antigen $(H L A)$ alleles $D R B 1^{*} 03: 01, D R B 1^{*} 04: 01, D R B 1^{*} 04: 05$ in North Indian patients, suggesting their integrated roles in manifestation of T1D. Based on the reported role of PTPN22 1858CT genotype in defective innate immune responses against viral infections, and defects in early T cell signaling, it is tempting to speculate that it may be detrimental for the destruction of pancreatic beta cells in the present scenario.

Keywords: PTPN22; Major histocompatibility complex; Type 1 diabetes

\section{Introduction}

Type 1 diabetes (T1D) is a multifactorial autoimmune disorder where insulin producing pancreatic beta cells are lost before the manifestations of the disease. It has an incidence of 10.5/100,000/ year in India [1]. Several genetic and environmental factors have been implicated as the causative factors, however, a role of complex interaction of these factors leading to the autoimmune destruction of the pancreatic beta cells cannot be ruled out [2]. The cell-mediated autoimmune destruction of pancreatic beta cells is brought about by infiltrating macrophages and lymphocytes in the pancreatic islets, the phenomenon known as Insulitis. While the function of most T-cells is to mount host-defense response, regulatory T-cells are programmed to moderate the reactivity of effector T-cells, in order to protect the body from autoimmune responses. It has been proposed that an increase in the ratio of effector T-cells to regulatory T-cells may result in autoimmunity in T1D [3]. Both $\mathrm{CD} 4^{+}$helper $\mathrm{T}$ cells and $\mathrm{CD} 8^{+}$Cytotoxic $\mathrm{T}$ cells are the effector T cells required to induce beta cell autoimmunity [4]. Defects in $\mathrm{T}$ cell signaling may be involved in altering the ratios of effector and regulatory $\mathrm{T}$ cells.

Of the 20 genomic intervals implicated in the predisposition for development of T1D [5], we and others have reported association of T1D with the major histocompatibility complex (MHC) alleles on chromosome $6 \mathrm{p} 21$ and the 5' regulatory region of the insulin (INS) gene on 11p15.5 in North Indians and other ethnic groups [6-8].
Besides, we have also reported association and interaction of TNF- $\alpha$ gene with other cytokine genes [9], Vitamin D receptor gene (VDR) and their role in expression of predisposing $M H C$ allele in manifestation of T1D [10]. Interestingly, it seems that several genes have integrated roles in manifestation of the disease since simultaneous presence of different alleles of two or more genes seem to be significantly increased in T1D patients. For instance, simultaneous presence of HLA $D R B 1^{\star} 0301$, $D R B 1^{\star} 0401$ and/or $D R B 1^{\star} 0405$ along with class-I alleles of INS-linked variable number of tandem repeats (VNTR) were very significantly associated with T1D [6]. Similarly an interaction was observed between $V D R$ gene and predisposing $H L A$ alleles, and this interaction of $V D R$ with $D R B 1^{*} 0301$ was through the vitamin D response element (VDRE) present in the promoter region of the predisposing HLA allele and was involved in regulating the expression of $H L A-D R B 1^{*} 0301$ [10]. Besides

*Corresponding author: Rajni Rani, Molecular Immunogenetics Group, National Institute of Immunology, Aruna Asaf Ali Marg, New Delhi-110067, India, Tel: 9111 26703545; Fax: 9111-26742125; E-mail: rajni@nii.ac.in

Received January 28, 2014; Accepted February 28, 2014; Published March 05, 2014

Citation: Rani R, Israni N, Kumar A, Vasudevan S, Singh J (2014) Association of Protein Tyrosine Phosphatase Non-receptor, Type 22 (PTPN22) C1858T Polymorphism with Type 1 Diabetes in North India: A Replication Study. J Diabetes Metab 5: 342. doi:10.4172/2155-6156.1000342

Copyright: (c) 2014 Rani R, et al. This is an open-access article distributed unde the terms of the Creative Commons Attribution License, which permits unrestricted use, distribution, and reproduction in any medium, provided the original author and source are credited. 
$M H C$, INS, cytokine and VDR genes, there are several other genes that have been shown to be associated with T1D which include CTLA4 gene located on chromosome $2 \mathrm{q} 33[11,12]$ and PTPN22 gene located on chromosome 1 p13 [4].

The PTPN22 (Protein tyrosine phosphatase non-receptor, type 22) gene codes for lymphoid tyrosine phosphatase (LYP) which is an 807 amino acid residue protein with a molecular weight of $110 \mathrm{kDa}$ and is involved in negative regulation of T cell signaling [13-15]. A single nucleotide polymorphism (SNP) in the PTPN22 gene at nucleotide position $1858 C>T$ results in the amino acid change from arginine (R) to tryptophan (W) ( $\underline{C} G G$ to $\underline{T} G G$ ) at codon 620 which has been shown to be a gain-of-function mutant [16]. The negative regulation of $\mathrm{T}$ cells by LYP is brought about by its dissociation from C-terminal Src kinase (CSK) and recruitment of LYP to the plasma membrane where it down-regulates TCR signaling. LYP ${ }^{\star}$ W620, however, cannot bind CSK and negatively regulates LCK-mediated phosphorylation of the TCR $\xi$ chain, reduces tyrosine phosphorylation of LAT and reduces activation of ERK2 as compared to $\mathrm{LYP}^{\star} \mathrm{R} 620$. In essence, $\mathrm{LYP}^{\star} \mathrm{W} 620$ has been reported be more efficient at dephosphorylation than $L Y P * R 620[15,16]$. Several autoimmune disorders like systemic lupus erythematosus [17], rheumatoid arthritis $[18,19]$ and type 1 diabetes [20-22] have been shown to be associated with the mutant $T$ allele i.e., LYP ${ }^{\star}$ W620.

The allele frequency of the minor $1858 \mathrm{~T}$ allele varies from $0 \%$ in some Asian populations [23] to 8-17\% in different ethnic groups of European origin [17,18,24]. Africans [24] also have a very low frequency of the minor $1858 \mathrm{~T}$ allele [10]. Such ethnic differences make it important to study the role of the minor allele in manifestations of autoimmune disorders in different populations. While earlier studies reported absence of $1858 \mathrm{~T}$ allele in Asia [23], we had reported a very low frequency (2.03\%) of this allele in normal healthy individuals [25]. In spite of this low frequency in the normal population, we observed a disease specific increase in the frequency of $1858 \mathrm{~T}$ allele in leprosy patients. So, we investigated if the same was true for T1D as well, since several reports have shown association of $1858 \mathrm{~T}$ allele with Type 1 diabetes in different ethnic groups [4,20-22], however, there are no studies reported so far from the Indian sub-continent with respect to PTPN22 polymorphism in T1D, probably due to presumption that the allele is absent in Asian populations. Here, we report the association of PTPN22 $1858 T$ allele and its association with predisposing MHC class$I I$ alleles in T1D in patients from North India.

\section{Materials and Methods}

Two hundred and Fifty T1D patients and 480 normal healthy controls based in Delhi, originally from North Indian states of Uttar Pradesh, Haryana and Punjab, were studied after obtaining informed consent from patients and controls and Institutional Human Ethics Committee's clearance from National Institute of Immunology and All India Institute of Medical Sciences, New Delhi, India. The patient group consisted of 106 females and 144 males with a mean age of $25.96 \pm 9.79$ and age at onset of diabetes $<30$ years (Mean age at onset $\pm S D=15.995$ \pm 7.43 ), attending 'Juvenile Diabetes Clinic' at the All India Institute of Medical Sciences, Delhi, India. All the patients attending 'Juvenile Diabetes Clinic' were carefully assessed and categorized as type 1, type 2 and fibrocalculous pancreatopathy according to the classification of the American Diabetes Association expert committee [26] as reported earlier $[9,10]$. Controls included 480 healthy subjects (135 women and 345 men), with a mean age \pm SD of $30.16 \pm 9.02$.

For controls, we preferred higher age group to rule out their possibility of developing T1D at a later date after the collection of their blood samples as normal healthy controls. Controls were asked for their clinical history and only those without any history of infectious or autoimmune diseases were included in the study.

DNA was extracted using a standard protocol from $10 \mathrm{ml}$ of blood from T1D patients and healthy controls from the same ethnic background after obtaining informed consent and Institutional Ethics Committee's approval.

\section{PTPN22 Genotyping using PCR-RFLP Polymerase Chain Reaction followed by restriction fragment length polymorphism}

The genotyping for PTPN22 single nucleotide polymorphism at position C1858T in the codon 620 was carried out using PCRRFLP methods where standard PCR protocol was followed by restriction digestion of the PCR amplified product with restriction enzyme Rsa1. Primers used for amplification were forward primer (5'-ACTGATAATGTTGCTTCAA-3) and reverse primer (5'-TCACCAGCTTCCTCAACCA-3'), as described by Zheng et al., 2005 (Genbank accession \# AL 137856). Briefly, $100 \mathrm{ng}$ of genomic DNA $(5 \mu \mathrm{l})$ was mixed with $2.5 \mu \mathrm{l}$ of $10 \mathrm{X}$ buffer, $0.25 \mu \mathrm{l}$ of dNTPs $(100$ $\mathrm{mM}), 2.5 \mu \mathrm{l} \mathrm{MgCl}_{2}(25 \mathrm{mM}), 2.0 \mu \mathrm{l}(5 \mathrm{pm} / \mu \mathrm{l})$ each of the primers, and $0.125 \mu \mathrm{l}(5 \mathrm{U} / \mu \mathrm{l})$ of Taq polymerase in $25 \mu \mathrm{l}$ reaction volume. After initial denaturation at $94^{\circ} \mathrm{C}$ for 2 minutes, 35 cycles of denaturation at $94^{\circ} \mathrm{C}$, annealing at $60^{\circ} \mathrm{C}$ and extension at $72^{\circ} \mathrm{C}$, each for 30 seconds, were carried out followed by final extension cycle at $72^{\circ} \mathrm{C}$ for 7 minutes in Gene Amp 2700 thermocycler (Applied Biosystems, CA, USA). After confirmation of the amplified products on $1 \%$ Agarose gel, $10 \mu \mathrm{l}$ each of the amplified products were digested with $5 \mathrm{U}$ of RsaI enzyme (New England Biolabs) overnight at $37^{\circ} \mathrm{C}$. The digested PCR products were run on $2.5 \%$ agarose gel in $0.5 \mathrm{X}$ TBE buffer along with $50 \mathrm{bp}$ ladder. The restriction endonuclease Rsa 1 cleaves the DNA strand which contains the $C$ nucleotide at $1858^{\text {th }}$ position and gives two bands of $176 \mathrm{bp}$ and 42 bp sizes, the mutant $1858 T$, however, is not digested by Rsa 1 and gives a single band of $218 \mathrm{bp}$ size (Figure 1 ).

\section{HLA-DRB1 polymorphism}

Alleles of HLA-DRB1 locus were determined for 243 T1D patients

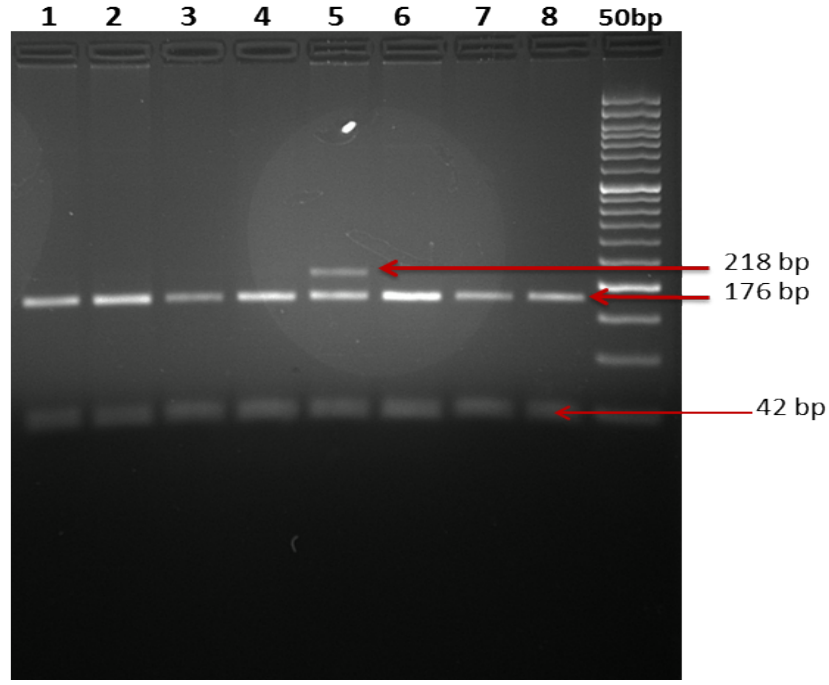

Figure 1: A representative picture of PCR-RFLP of PTPN22 C1858T on $2.5 \%$ Agarose gel: lanes 1-4 and 6-8 show homozygous $1858 C C$ genotype with 176 bp and 42 bp bands. Lane 5 shows heterozygous $1858 C T$ genotype with 218 bp, 176 bp and 42 bp bands, last lane is 50 bp ladder. 
and 327 controls for whom PTPN22 C1858T data was available. For 100 patient samples and 94 controls samples, the second exons of the DRB1 genes were PCR amplified using standard conditions and hybridized with ${ }^{32} \mathrm{P}$-labeled sequence specific oligonucleotide probes (SSOP) as described earlier [6,9]. For additional 143 patients and 233 control samples, Luminex based typing was done using Labtype SSO kit from One Lambda, (Canoga Park, CA, USA) according to the manufacturer's instructions as described earlier [9]. Briefly, $40 \mathrm{ng}$ of DNA was amplified in master mix, primers and $2 \mu \mathrm{l}$ of Taq DNA polymerase in Gene Amp 2700 thermocycler (Applied Biosystems, CA, USA). After confirmation of amplification, on $1 \%$ agarose gel, $5 \mu \mathrm{l}$ of amplified product was denatured and hybridized with appropriate amount of multiplex beads conjugated with oligonucleotide probes, in hybridization buffer at $60^{\circ} \mathrm{C}$ for 15 minutes followed by washings and incubation with $50 \mu \mathrm{l} 1 \mathrm{X}$ SAPE solution (Steptavidin Phycoerythin) at $60^{\circ} \mathrm{C}$ for 5 minutes. Fluorescence of the labeled beads was acquired on Luminex 2.2 flow cytometer (Luminex corporation, Austin, TX). Acquired data was analysed using Labtype software provided by One Lambda for analysis of MHC alleles. Reproducibility of the Luminex based HLA typing method had been checked by us earlier [9].

\section{Statistical analysis}

Chi-square test was used to examine the statistically significant differences between patients and controls using Stata 9.2 software. Odds Ratios and $95 \%$ confidence Intervals were also calculated using the same software. $p$ values were corrected using Bonferroni's correction for multiple comparisons. Fisher's exact test was used whenever the numbers in any group were less than 5 i.e. in cases or controls for any allele. In such cases, Odds ratios were calculated using Woolf's method [27] with Haldane's [28] modification as described earlier [29].

\section{Results}

We have genotyped 250 T1D patients and 480 healthy controls from the same ethnic background for C1858T alleles of PTPN22 as shown in Figure 1. Table 1 shows that that the mutant $1858 \mathrm{~T}$ allele is significantly increased in patients with T1D as compared to controls $(\mathrm{p}<0.0004$, Odds Ratio $=2.82,95 \%$ confidence Interval $=1.49-5.4)$. While homozygous genotype $C C$ was significantly reduced ( $<0.0003$, Odds Ratio $=0.34,95 \%$ confidence Interval $=0.18-0.65$ ), heterozygous $C T$ was significantly increased in T1D patients compared to controls $(\mathrm{p}<0.0003$, Odds Ratio $=2.93$, 95\% confidence Interval=1.53-5.71). And these differences remained significant even after Boneferroni's correction. All genotype frequencies in patients as well as controls were in Hardy Weinberg equilibrium.

To study if there was any gender bias, we stratified the samples for association of $1858 C T$ genotype with gender of the patients. While genotype $C T$ and $T$ allele were significantly increased in both males and females when compared to male and female controls respectively, the association was stronger in females (for $C T \mathrm{p}<0.002, \mathrm{OR}=6.4$ and for $T \mathrm{p}<0.003, \mathrm{OR}=6.12$ ) since the frequencies of $C T$ genotype and $T$ allele were much less in female controls ( $1.5 \%$ and $0.75 \%$ respectively) compared to male controls ( $4.9 \%$ and $2.51 \%$ respectively), although the same were comparable in male and female patients (Table 2).

We further checked whether $C T$ genotype and $T$ allele had any significant association with age at the onset of T1D (Table 3). For this we divided the patients in two groups based on their ages at the onset of the disease i.e., more than (>) 14 years and less than or equal to $(\leq) 14$ years. Interestingly, while both age groups had significant association with the predisposing genotype $C T$ and allele $T$, patients who had early age at onset i.e. $\leq 14$ years showed more significant association (for $C T$ $\mathrm{p}<0.0007, \mathrm{OR}=3.13$, for $T \mathrm{p}<0.0008, \mathrm{OR}=3.15)$.

We had earlier reported HLA-DRB1 ${ }^{\star} 03: 01,{ }^{\star} 04: 01$ and 04:05 to be predisposing for T1D in North Indians [6], To study the role of predisposing HLA alleles in combination with the PTPN22 alleles, 243 T1D patients and 327 normal healthy controls who were studied for PTPN22 C1858T were also typed for HLA-DRB1 locus alleles. Our results were in accordance with the earlier results i.e. all three alleles, HLA-DRB ${ }^{\star} 03: 01,{ }^{\star} 04: 01$ and 04:05 were significantly increased in T1D patients (Table 4 ) and $D R B 1^{* 07: 01}$ was significantly reduced in the patients as compared to healthy controls. Simultaneous presence of PTPN22 1858CT and 1858CC along with predisposing HLA alleles was investigated and interestingly both PTPN22 1858CT and 1858CC along with $H L A-D R B 1^{*} 03: 01$ were significantly increased in the T1D patients

\begin{tabular}{|c|c|c|c|c|c|c|c|}
\hline \multirow[t]{2}{*}{ Allele/Genotype } & \multicolumn{2}{|c|}{ T1D Patients $\mathbf{N}=250$} & \multicolumn{2}{|c|}{ Controls $\mathrm{N}=480$} & \multicolumn{3}{|c|}{ T1D vs. Controls } \\
\hline & $\mathbf{n}$ & $\%$ & n & $\%$ & p & Odds Ratio & 95\% C.I. \\
\hline Allele1858C & 473 & 94.6 & 941 & 98.02 & 0.0004 & 0.35 & $0.18-0.67$ \\
\hline Allele1858T & 27 & 5.4 & 19 & 1.98 & 0.0004 & 2.82 & $1.49-5.4$ \\
\hline Genotype CC & 223 & 89.2 & 461 & 96.04 & 0.0003 & 0.34 & $0.18-0.65$ \\
\hline Genotype $C T$ & 27 & 10.8 & 19 & 3.96 & 0.0003 & 2.93 & $1.53-5.71$ \\
\hline
\end{tabular}

Table 1: Allele and genotype frequencies of PTPN22 C1858T in T1D as compared to normal healthy controls.

\begin{tabular}{|c|c|c|c|c|c|c|c|c|c|c|}
\hline \multirow[t]{2}{*}{ Allele/Genotype } & \multirow{2}{*}{$\begin{array}{c}\text { T1D Male } \mathrm{N}=144 \\
\mathrm{n}(\%)\end{array}$} & \multirow{2}{*}{$\begin{array}{c}\text { T1D } \\
\text { Female } \\
\mathrm{N}=106 \\
\mathrm{n}(\%)\end{array}$} & \multirow{2}{*}{$\begin{array}{c}\begin{array}{c}\text { Controls } \\
\text { Male } \mathrm{N}=345\end{array} \\
\mathrm{n}(\%)\end{array}$} & \multirow{2}{*}{$\begin{array}{c}\text { Controls } \\
\text { Female } \\
\mathrm{N}=135\end{array}$} & \multicolumn{3}{|c|}{ Male T1D vs. Male Controls } & \multicolumn{3}{|c|}{ Female T1D vs. Female Controls } \\
\hline & & & & & $p$ value & Odds Ratio & 95\% C.I. & $p$ value & Odds Ratio & 95\% C.I. \\
\hline Allele $1858 \mathrm{C}$ & $272(94.4)$ & $\begin{array}{c}201 \\
(94.8)\end{array}$ & $\begin{array}{c}673 \\
(97.5)\end{array}$ & $\begin{array}{c}268 \\
(99.25)\end{array}$ & 0.015 & 0.43 & $0.2-0.9$ & $0.003^{*}$ & $0.16^{* *}$ & $0.06-0.43$ \\
\hline Allele1858T & $\begin{array}{c}16 \\
(5.6)\end{array}$ & $\begin{array}{c}11 \\
(5.2)\end{array}$ & $\begin{array}{c}17 \\
(2.5)\end{array}$ & $\begin{array}{c}2 \\
(0.75)\end{array}$ & 0.015 & 2.33 & $1.08-4.97$ & $0.003^{*}$ & $6.12^{* *}$ & $2.3-16.26$ \\
\hline Genotype CC & $128(88.9)$ & $\begin{array}{c}95 \\
(89.6)\end{array}$ & $\begin{array}{c}328 \\
(96.1)\end{array}$ & $\begin{array}{c}133 \\
(98.5)\end{array}$ & 0.013 & 0.41 & $0.19-0.9$ & $0.002^{*}$ & $0.15^{* *}$ & $0.05-0.42$ \\
\hline Genotype $C T$ & $\begin{array}{c}16 \\
(11.1)\end{array}$ & $\begin{array}{c}11 \\
(10.4)\end{array}$ & $\begin{array}{c}17 \\
(4.9)\end{array}$ & $\begin{array}{c}2 \\
(1.5)\end{array}$ & 0.013 & 2.4 & $1.1-5.2$ & $0.002^{*}$ & $6.4^{* *}$ & $2.4-17.2$ \\
\hline
\end{tabular}

*Fisher's exact test was used to calculate $p$ values.

"Haldane's modification was used to calculate the Odds Ratio.

Table 2: Gender-wise distribution of allele and genotype frequencies of PTPN22 C1858T in T1D as compared to matched normal healthy controls (07.01.14). 
Citation: Rani R, Israni N, Kumar A, Vasudevan S, Singh J (2014) Association of Protein Tyrosine Phosphatase Non-receptor, Type 22 (PTPN22) C1858T Polymorphism with Type 1 Diabetes in North India: A Replication Study. J Diabetes Metab 5: 342. doi:10.4172/2155-6156.1000342

Page 4 of 6

\begin{tabular}{|c|c|c|c|c|c|c|c|c|c|}
\hline \multirow[t]{2}{*}{ Allele/ Genotype } & \multirow{2}{*}{$\begin{array}{c}\text { T1D } \\
>14 \text { years } \\
\mathrm{N}=133 \\
\mathrm{n}(\%)\end{array}$} & \multirow{2}{*}{$\begin{array}{c}\text { T1D } \\
\leq 14 \text { years } \\
\mathrm{N}=117 \\
\mathrm{n}(\%)\end{array}$} & \multirow{2}{*}{$\begin{array}{c}\begin{array}{c}\text { Controls } \\
\mathrm{N}=480\end{array} \\
\mathrm{n}(\%)\end{array}$} & \multicolumn{3}{|c|}{ Age at onset $>14$ years vs. controls } & \multicolumn{3}{|c|}{ Age at onset $\leq 14$ years vs. controls } \\
\hline & & & & p value & Odds Ratio & 95\% C.I. & $p$ value & Odds Ratio & 95\% C.I. \\
\hline Allele1858C & $\begin{array}{c}253 \\
(95.1)\end{array}$ & $\begin{array}{c}220 \\
(94.0)\end{array}$ & $\begin{array}{c}941 \\
(98.02)\end{array}$ & 0.008 & 0.39 & $0.18-0.88$ & 0.0008 & 0.32 & $0.15-0.69$ \\
\hline Allele1858T & $\begin{array}{c}13 \\
(4.9)\end{array}$ & $\begin{array}{c}14 \\
(5.98)\end{array}$ & $\begin{array}{c}19 \\
(1.98)\end{array}$ & 0.008 & 2.54 & $1.1-5.5$ & 0.0008 & 3.15 & $1.43-6.73$ \\
\hline Genotype CC & $\begin{array}{c}120 \\
(90.2)\end{array}$ & $\begin{array}{c}103 \\
(88.1)\end{array}$ & $\begin{array}{c}461 \\
(96.04)\end{array}$ & 0.0076 & 0.38 & $0.17-0.86$ & 0.0007 & 0.3 & $0.14-0.68$ \\
\hline Genotype $C T$ & $\begin{array}{c}13 \\
(9.8)\end{array}$ & $\begin{array}{c}14 \\
(11.9)\end{array}$ & $\begin{array}{c}19 \\
(3.96)\end{array}$ & 0.0076 & 2.62 & $1.1-5.8$ & 0.0007 & 3.3 & $1.5-7.2$ \\
\hline
\end{tabular}

Table 3: Genotype frequencies of PTPN22 C1858T in T1D based on age at onset as compared to normal healthy controls (07.01.14).

\begin{tabular}{|c|c|c|c|c|c|c|c|}
\hline \multirow[t]{2}{*}{ Allele/Genotype } & \multicolumn{2}{|c|}{ T1D Patients $\mathrm{N}=\mathbf{2 4 3}$} & \multicolumn{2}{|c|}{ Controls $\mathrm{N}=\mathbf{3 2 7}$} & \multirow[t]{2}{*}{$\mathbf{p}$} & \multirow[t]{2}{*}{ Odds Ratio } & \multirow[t]{2}{*}{ 95\% C.I. } \\
\hline & $\mathbf{n}$ & $\%$ & $\mathbf{n}$ & $\%$ & & & \\
\hline$D R B 1^{*} 03: 01$ & 188 & 77.4 & 52 & 15.9 & $6.58 \times 10^{-49}$ & 18.07 & $11.61-28.21$ \\
\hline$D R B 1^{*} 04: 01$ & 28 & 11.5 & 8 & 2.45 & 0.00001 & 5.19 & $2.24-13.4$ \\
\hline$D R B 1^{*} 04: 03$ & 8 & 3.29 & 29 & 8.87 & 0.0075 & 0.35 & $0.13-0.8$ \\
\hline$D R B 1^{*} 04: 05$ & 22 & 9.05 & 1 & 0.31 & $5.71 \times 10^{-8^{*}}$ & $22.11^{* *}$ & $6.82-71.59$ \\
\hline$D R B 1^{*} 07: 01$ & 30 & 12.35 & 103 & 31.5 & $8.96 \times 10^{-8}$ & 0.31 & $0.19-0.49$ \\
\hline
\end{tabular}

Fisher's exact test was used to calculate $p$ values.

"Haldane's modification was used to calculate the Odds Ratio.

Table 4: Frequencies of predisposing HLA-DRB1 alleles In T1D patients and controls typed for PTPN22 C1858T.

\begin{tabular}{|c|c|c|c|c|c|c|c|}
\hline \multirow{2}{*}{$\begin{array}{l}P T P N 22 C C / C T \text { with predisposing } \\
\text { and protective } H L A \text { alleles }\end{array}$} & \multicolumn{2}{|c|}{ T1D N=243 } & \multicolumn{2}{|c|}{ Controls $\mathrm{N}=327$} & \multirow[t]{2}{*}{$\mathbf{p}$} & \multirow[t]{2}{*}{ Odds ratio } & \multirow[t]{2}{*}{ 95\% C.I. } \\
\hline & $\mathrm{n}$ & $\%$ & $\mathrm{n}$ & $\%$ & & & \\
\hline$C T-H L A-D R B 1^{*} 03: 01$ & 24 & 9.9 & 3 & 0.91 & $6.34 \times 10^{-7^{*}}$ & $10.34^{* *}$ & $4.64-23.05$ \\
\hline$C C-H L A-D R B 1^{*} 03: 01$ & 164 & 67.9 & 49 & 14.98 & $1.36 \times 10^{-37}$ & 11.77 & $7.71-18.05$ \\
\hline$C T-H L A-D R B 1^{*} 04: 01$ & 2 & 0.82 & 0 & 0 & $0.18^{*}$ & $6.78^{* *}$ & $0.78-58.22$ \\
\hline CC- HLA-DRB1*04:01 & 26 & 10.7 & 8 & 2.453 & $0.00003^{*}$ & $4.78^{* *}$ & $2.05-12.41$ \\
\hline$C T-H L A-D R B 1^{*} 04: 03$ & 0 & 0 & 0 & 0 & - & - & - \\
\hline$C C-H L A-D R B 1^{*} 04: 03$ & 8 & 3.3 & 29 & 8.86 & 0.0075 & 0.35 & $0.14-0.8$ \\
\hline CT- HLA-DRB1*04:05 & 2 & 0.82 & 0 & 0 & $0.18^{*}$ & $6.78^{* *}$ & $0.78-58.22$ \\
\hline$C C-H L A-D R B 1^{*} 04: 05$ & 20 & 8.23 & 1 & 0.31 & $3.17 \times 10^{-7^{*}}$ & $19.96^{* *}$ & $6.14-64.87$ \\
\hline$C T-H L A-D R B 1^{*} 07: 01$ & 3 & 1.23 & 5 & 1.53 & $0.53^{*}$ & $0.85^{* *}$ & $0.33-2.22$ \\
\hline$C C-H L A-D R B 11^{*} 07: 01$ & 27 & 11.11 & 98 & 29.97 & $7.39 \times 10^{-8}$ & 0.29 & $0.17-0.47$ \\
\hline
\end{tabular}

*Fisher's exact test was used to calculate $p$ values

"Haldane's modification was used to calculate the Odds Ratio.

Table 5: Association of predisposing PTPN22 C1858T allele with predisposing HLA alleles.

as compared to controls (Table 5), suggesting that while predisposing HLA alleles have a dominant effect, association of PTPN22CT genotype is independent of $M H C$ associations.

\section{Discussion}

Several genes have been implicated for predisposition to develop T1D. While the $M H C$ region has been shown to account for $50 \%$ of the inherited risk [8], an integrated role of other genes like INS-VNTR, CTLA-4, Vitamin D receptor (VDR), cytokine genes and PTPN22 amongst a number of other genes cannot be ruled out $[6,9,10,12,30,31]$ since it is a very complex autoimmune disorder where most of the implicated genes have some functional relevance. For example, INSVNTR class-I alleles have been shown to have poor expression of insulin in thymii of fetuses as compared to those with Class-III alleles $[32,33]$ which may be responsible for poor thymic education for insulin resulting in autoimmunity against insulin producing pancreatic beta cells [32,33]. Similarly, the products of CTLA-4 and PTPN22 genes have roles in negative $\mathrm{T}$ cell signaling. CTLA- 4 is constitutively expressed on regulatory $\mathrm{T}$ cells $[34,35]$ and defect in CTLA- 4 expression may be detrimental for the manifestations of autoimmunity since autoimmune responses may not be regulated in these cases [35].

The other negative regulator of T cell signaling, PTPN22 with SNP C1858T, has been implicated in many autoimmune disorders $[18,19,36]$ and was first reported by Bottini et al. in Type 1 diabetes patients from two independent populations [4,37], followed by several reports where the associations were reported with either T1D per se, or with female gender or with beta cell dysfunction or autoantibodies and even with early age at onset in children fed with cow milk formula, in different populations [20-22,38-41]. Our observations replicated earlier reports, and show a significantly higher number of T1D patients from North India to have $1858 C T$ genotype and $T$ allele as compared to controls $[37,39,42,43]$. Fedetz et al. [42], observed a significantly higher number of T1D patients from Ukraine to have $T T$ genotype and $T$ allele as compared to healthy controls. They also observed the association was stronger in female patients and in those at younger age at onset, similar to our findings where $1858 \mathrm{CT}$ genotype showed stronger association in female patients and early age at onset. 
While we do find a significant increase of $T$ allele and $C T$ genotype in T1D patients, total absence of homozygous 1858TT genotype was surprising. Under normal Mendelian inheritance pattern, one would expect some homozygous TTs as well since $10.8 \%$ of the patients had heterozygous $C T$ genotype. However, since the frequency of the $T$ allele is very low in healthy controls, the chances of getting homozygous TT would probably be very low. While no association of $1858 T$ allele was observed with T1D in Japanese population, another SNP in the region, rs1310182, was significantly associated in them. In fact, this nucleotide position C1858T was reported to be non-polymorphic in Japanese [44]. Frequency of $1858 \mathrm{~T}$ alleles varies in different populations. While we observed a very low frequency of $1858 \mathrm{~T}$ allele in North Indians [25], earlier studies reported a total absence of $T$ allele in Asian populations [23]. Our study suggests that Asian populations cannot be generalized as one ethnic group since the earlier reports of absence of the $T$ allele have been from Asian populations from Japan, Korea and China, which being Mongoloid in origin, are ethnically different from Indians who are basically Caucasoid with racial admixture of Mongoloid and Negroid elements [45].

Our data further suggests that association of PTPN221858CT genotype was independent of the predisposing $\mathrm{MHC}$ alleles, suggesting that the primary association is with $D R B 1^{\star} 03: 01$ which was observed in $77.4 \%$ of T1D patients, compared to $10.8 \%$ of the patients having PTPN221858CT genotype. Recently several papers have been published on functional relevance of the PTPN22 $1858 T$ or LYP*W620 allele, where PTPN22 encoded LYP has been shown to have roles in both innate and adaptive immune responses. Expression of LYP ${ }^{\star}$ W620 has been associated with reduced TLR signaling resulting in defective type 1 IFN-mediated host response to infection which may have role in initiation of T1D that is associated with viral infection [46]. Also, LYP negatively regulates $\mathrm{T}$ cell functions by dissociating from $\mathrm{C}$-terminal Src tyrosine kinase (CSK) which is essential for recruitment of LYP to the lipid rafts where it regulates TCR mediated signaling. And the disease associated $\mathrm{LYP}^{\star} \mathrm{W} 620$ (1858T allele) was shown to partition into lipid rafts more efficiently than LYP ${ }^{\star} 620$ due to its inefficiency to bind CSK and was thus shown to be more potent inhibitor of TCR induced responses [15].

Type 1 diabetes is a multifactorial disease with several components like a jigsaw puzzle with several genomic loci implicated in the manifestation of the disease. We have been trying to put some of the pieces of the puzzle together where some components are interrelated while others are independently affecting the manifestations in the presence of other predisposing factors. We have reported earlier that simultaneous presence of $D R B 1^{\star} 0301$ along with homozygous INS-VNTR class-I alleles was significantly increased $\left(\mathrm{p}<10^{-8}\right)$ in T1D patients, giving a relative risk of 70.81 [6]. We also provided evidence of statistically significant interaction between the predisposing $H L A$ allele and high producer alleles of $V D R$ which may be detrimental for the manifestation of T1D in the absence of $1,25-(47)_{2} \mathrm{D}_{3}$ in early childhood and/or in-utero. Our studies on HLA-DRB1*03:01 homozygous cell lines showed enhanced expression of HLA-DR on the B-LCLs stimulated with $100 \mathrm{nM}$ calcitriol as compared to the unstimulated ones confirming that indeed the interaction of VDR with $H L A-D R B 1^{*} 03: 01$ is occurring through the VDRE present in the promoter region of the gene [10]. Based on these studies we speculated that in the absence of required amount of Vitamin D in early life in the predisposed individuals with $H L A-D R B 1^{*} 0301$, the expression of the allele may be impaired in the thymus $[47,48]$ resulting in escape from thymic deletion of autoreactive T cells leading to T1D manifestations. Poor thymic education for insulin and HLA-DRB $1^{\star} 03: 01$ proteins along with environmental factors like viral infections, vitamin D deficiency and some milk proteins may be involved in initiation of the autoimmune responses against the pancreatic beta cells. While predisposing HLA class-II molecules may be involved in auto-antigen presentation to $\mathrm{T}$ helper cells, higher producing genotypes of pro-inflammatory cytokines like IFN-gamma and TNF-alpha may be involved in enhancing the cell mediated immune responses through proliferation of $\mathrm{CD} 4^{+}$and $\mathrm{CD} 8^{+} \mathrm{T}$ cells, and higher producing genotypes of $I L-10$ and TGF-beta may have a role in recruitment of these autoreactive $\mathrm{T}$ cells in the pancreas through ICAM-1 and Integerin dependent pathways [9]. Additionally, PTPN22 1858CT genotype may have a role in defective innate immune responses against viral infections that may trigger islet cell autoimmunity [46] combined with defects in early $\mathrm{T}$ cell signaling due to which autoreactive $\mathrm{T}$ cells may not be deleted and may lead to insufficient activity of regulatory $\mathrm{T}$ cells, thus leading to autoimmune $[4,16]$ destruction of pancreatic beta cells which may occur through $\mathrm{CD} 4^{+}$and $\mathrm{CD} 8^{+} \mathrm{T}$ cells and nitric oxide production.

\section{Author Contribution}

RR conceived the project and critically evaluated the data, NI, AK SV and JS were involved in generating the Type1 diabetes and control data for PTPN22 and $H L A$. RR analysed the data and wrote the manuscript.

\section{Acknowledgements}

Authors are thankful to study participants for providing blood samples without which the study would not have been possible. We would like to thank our collaborator, Dr. Ravinder Goswami, Department of Endocrinology and Metabolism, All India Institute of Medical Sciences for T1D patient samples. Mr. Kapoor Chand's technical support is acknowledged. This work was supported by grant from Department of Science \& Technology, New Delhi, India, grant No. SPI SO/B54/98 and core grant from National Institute of Immunology, New Delhi, India.

\section{References}

1. Ramachandran A, Snehalatha C, Krishnaswamy CV (1996) Incidence of IDDM in children in urban population in southern India. Madras IDDM Registry Group Madras, South India. Diabetes Res Clin Pract 34: 79-82.

2. Permutt MA, Wasson J, Cox N (2005) Genetic epidemiology of diabetes. J Clin Invest 115: 1431-1439.

3. Kim MS, Polychronakos C (2005) Immunogenetics of type 1 diabetes. Horm Res 64: 180-188.

4. Bottini N, Vang T, Cucca F, Mustelin T (2006) Role of PTPN22 in type 1 diabetes and other autoimmune diseases. Semin Immunol 18: 207-213.

5. Pociot F, McDermott MF (2002) Genetics of type 1 diabetes mellitus. Genes Immun 3: 235-249.

6. Rani R, Sood A, Goswami R (2004) Molecular basis of predisposition to develop type 1 diabetes mellitus in North Indians. Tissue Antigens 64: 145-155.

7. Todd JA (1995) Genetic analysis of type 1 diabetes using whole genome approaches. Proc Natl Acad Sci U S A 92: 8560-8565.

8. Anjos S, Polychronakos C (2004) Mechanisms of genetic susceptibility to type I diabetes: beyond HLA. Mol Genet Metab 81: 187-195.

9. Kumar R, Goswami R, Agarwal S, Israni N, Singh SK, et al. (2007) Association and interaction of the TNF-alpha gene with other pro- and anti-inflammatory cytokine genes and HLA genes in patients with type 1 diabetes from North India. Tissue Antigens 69: 557-567.

10. Israni N, Goswami R, Kumar A, Rani R (2009) Interaction of vitamin D receptor with HLA DRB1 0301 in type 1 diabetes patients from North India. PLoS One 4: e8023.

11. Lee YJ, Huang FY, Lo FS, Wang WC, Hsu CH, et al. (2000) Association of CTLA4 gene A-G polymorphism with type 1 diabetes in Chinese children. Clin Endocrinol (Oxf) 52: 153-157.

12. Baniasadi V, Narain N, Goswami R, Das SN (2006) Promoter region -318 C/ T and -1661 A/G CTLA-4 single nucleotide polymorphisms and type 1 diabetes in North Indians. Tissue Antigens 67: 383-389.

13. Hasegawa K, Martin F, Huang G, Tumas D, Diehl L, et al. (2004) PEST domainenriched tyrosine phosphatase (PEP) regulation of effector/memory $T$ cells Science 303: 685-689. 
Citation: Rani R, Israni N, Kumar A, Vasudevan S, Singh J (2014) Association of Protein Tyrosine Phosphatase Non-receptor, Type 22 (PTPN22) C1858T Polymorphism with Type 1 Diabetes in North India: A Replication Study. J Diabetes Metab 5: 342. doi:10.4172/2155-6156.1000342

14. Cohen S, Dadi H, Shaoul E, Sharfe N, Roifman CM (1999) Cloning and characterization of a lymphoid-specific, inducible human protein tyrosine phosphatase, Lyp. Blood 93: 2013-2024.

15. Vang T, Liu WH, Delacroix L, Wu S, Vasile S, et al. (2012) LYP inhibits T-cell activation when dissociated from CSK. Nat Chem Biol 8: 437-446.

16. Vang T, Congia M, Macis MD, Musumeci L, Orrú V, et al. (2005) Autoimmuneassociated lymphoid tyrosine phosphatase is a gain-of-function variant. Nat Genet 37: 1317-1319.

17. Kyogoku C, Langefeld CD, Ortmann WA, Lee A, Selby S, et al. (2004) Genetic association of the R620W polymorphism of protein tyrosine phosphatase PTPN22 with human SLE. Am J Hum Genet 75: 504-507.

18. Begovich AB, Carlton VE, Honigberg LA, Schrodi SJ, Chokkalingam AP, et al. (2004) A missense single-nucleotide polymorphism in a gene encoding a protein tyrosine phosphatase (PTPN22) is associated with rheumatoid arthritis. Am J Hum Genet 75: 330-337.

19. Burkhardt H, Huffmeier U, Spriewald B, Bohm B, Rau R, et al. (2006) Association between protein tyrosine phosphatase 22 variant $\mathrm{R} 620 \mathrm{~W}$ in conjunction with the HLA-DRB1 shared epitope and humoral autoimmunity to an immunodominant epitope of cartilage-specific type II collagen in early rheumatoid arthritis. Arthritis Rheum 54: 82-89.

20. Giza S, Goulas A, Gbandi E, Effraimidou S, Papadopoulou-Alataki E, et al. (2013) The role of PTPN22 C1858T gene polymorphism in diabetes mellitus type 1: first evaluation in Greek children and adolescents. Biomed Res Int 2013: 721604 .

21. Petrone A, Spoletini M, Zampetti S, Capizzi M, Zavarella S, et al. (2008) The PTPN22 1858T gene variant in type 1 diabetes is associated with reduced residual beta-cell function and worse metabolic control. Diabetes Care 31: 1214-1218.

22. Petrone A, Suraci C, Capizzi M, Giaccari A, Bosi E, et al. (2008) The protein tyrosine phosphatase nonreceptor 22 (PTPN22) is associated with high GAD antibody titer in latent autoimmune diabetes in adults: Non Insulin Requiring Autoimmune Diabetes (NIRAD) Study 3. Diabetes Care 31: 534-538.

23. Kawasaki E, Awata T, Ikegami H, Kobayashi T, Maruyama T, et al. (2006) Systematic search for single nucleotide polymorphisms in a lymphoid tyrosine phosphatase gene (PTPN22): association between a promoter polymorphism and type 1 diabetes in Asian populations. Am J Med Genet A 140: 586-593.

24. Chapman SJ, Khor CC, Vannberg FO, Maskell NA, Davies CW, et al. (2006) PTPN22 and invasive bacterial disease. Nat Genet 38: 499-500.

25. Rani R, Singh A, Israni N, Singh A, Sharma P, et al. (2009) The role of polymorphic protein tyrosine phosphatase non-receptor type 22 in leprosy. J Invest Dermatol 129: 2726-2728.

26. American Diabetes Association (2009) Standards of medical care in diabetes--2009. Diabetes Care 32: S13-61.

27. WOOLF B (1955) On estimating the relation between blood group and disease. Ann Hum Genet 19: 251-253.

28. HALDANE JB (1956) The estimation and significance of the logarithm of a ratio of frequencies. Ann Hum Genet 20: 309-311.

29. Rani R, Fernandez-Viña MA, Stastny P (1998) Associations between HLA class II alleles in a North Indian population. Tissue Antigens 52: 37-43.

30. Guja C, Marshall S, Welsh K, Merriman M, Smith A, et al. (2002) The study of CTLA-4 and vitamin D receptor polymorphisms in the Romanian type 1 diabetes population. J Cell Mol Med 6: 75-81.

31. Guo SW, Magnuson VL, Schiller JJ, Wang X, Wu Y, et al. (2006) Meta-analysis of vitamin $D$ receptor polymorphisms and type 1 diabetes: a HuGE review of genetic association studies. Am J Epidemiol 164: 711-724.

32. Pugliese A, Zeller M, Fernandez A Jr, Zalcberg LJ, Bartlett RJ, et al. (1997) The insulin gene is transcribed in the human thymus and transcription levels correlated with allelic variation at the INS VNTR-IDDM2 susceptibility locus for type 1 diabetes. Nat Genet 15: 293-297.
33. Vafiadis P, Bennett ST, Todd JA, Nadeau J, Grabs R, et al. (1997) Insulin expression in human thymus is modulated by INS VNTR alleles at the IDDM2 locus. Nat Genet 15: 289-292.

34. Teft WA, Kirchhof MG, Madrenas J (2006) A molecular perspective of CTLA-4 function. Annu Rev Immunol 24: 65-97.

35. Romo-Tena J, Gómez-Martín D, Alcocer-Varela J (2013) CTLA-4 and autoimmunity: new insights into the dual regulator of tolerance. Autoimmun Rev 12: 1171-1176.

36. Laberge GS, Birlea SA, Fain PR, Spritz RA (2008) The PTPN22-1858C>T (R620W) functional polymorphism is associated with generalized vitiligo in the Romanian population. Pigment Cell Melanoma Res 21: 206-208.

37. Bottini N, Musumeci L, Alonso A, Rahmouni S, Nika K, et al. (2004) A functional variant of lymphoid tyrosine phosphatase is associated with type I diabetes. Nat Genet 36: 337-338.

38. Kahles H, Ramos-Lopez E, Lange B, Zwermann O, Reincke M, et al. (2005) Sex-specific association of PTPN22 1858T with type 1 diabetes but not with Hashimoto's thyroiditis or Addison's disease in the German population. Eur J Endocrinol 153: 895-899.

39. Ladner MB, Bottini N, Valdes AM, Noble JA (2005) Association of the single nucleotide polymorphism C1858T of the PTPN22 gene with type 1 diabetes. Hum Immunol 66: 60-64

40. Chelala C, Duchatelet S, Joffret ML, Bergholdt R, Dubois-Laforgue D, et al (2007) PTPN22 R620W functional variant in type 1 diabetes and autoimmunity related traits. Diabetes 56: 522-526.

41. Lempainen J, Vaarala O, Mäkelä M, Veijola R, Simell O, et al. (2009) Interplay between PTPN22 C1858T polymorphism and cow's milk formula exposure in type 1 diabetes. J Autoimmun 33: 155-164.

42. Fedetz M, Matesanz F, Caro-Maldonado A, Smirnov II, Chvorostinka VN, et al (2006) The 1858T PTPN22 gene variant contributes to a genetic risk of type 1 diabetes in a Ukrainian population. Tissue Antigens 67: 430-433.

43. Smyth D, Cooper JD, Collins JE, Heward JM, Franklyn JA, et al. (2004) Replication of an association between the lymphoid tyrosine phosphatase locus (LYP/PTPN22) with type 1 diabetes, and evidence for its role as a general autoimmunity locus. Diabetes 53: 3020-3023.

44. Taniyama M, Maruyama T, Tozaki T, Nakano Y, Ban Y (2010) Association of PTPN22 haplotypes with type 1 diabetes in the Japanese population. Hum Immunol 71:795-798.

45. Rani R, Fernandez-Viña MA, Zhang S, Stastny P (1995) HLA-DPB1 alleles in a population from north India and description of a new variant (DPB1*5601) Tissue Antigens 45: 264-269.

46. Wang Y, Shaked I, Stanford SM, Zhou W, Curtsinger JM, et al. (2013) The autoimmunity-associated gene PTPN22 potentiates toll-like receptor-driven, type 1 interferon-dependent immunity. Immunity 39: 111-122.

47. Lim YS, Oh HB, Choi SE, Kwon OJ, Heo YS, et al. (2008) Susceptibility to type 1 autoimmune hepatitis is associated with shared amino acid sequences at positions 70-74 of the HLA-DRB1 molecule. J Hepatol 48: 133-139.

48. Ramagopalan SV, Maugeri NJ, Handunnetthi L, Lincoln MR, Orton SM, et al (2009) Expression of the multiple sclerosis-associated MHC class II Allele HLADRB1*1501 is regulated by vitamin D. PLoS Genet 5: e1000369. 